\title{
A comparative study of cognitive processes in students with deep versus superficial knowledge on interpreting graphs of mathematical functions based on Event-Related Potential
}

\author{
Najmeh Farsad ${ }^{1}$, Hassan Alamolhodaei ${ }^{2 *}(\mathbb{D})$, Ali Moghimi ${ }^{2}$, Sahar Moghimi ${ }^{3}$, Mehdi Jabbari Nooghabi ${ }^{4}$ \\ 1. PhD in Mathematics Education, Faculty of Mathematical Sciences, Ferdowsi University of Mashhad, Mashhad, Iran \\ 2. Professor of Department of Mathematics Education, Faculty of Mathematical Sciences, Ferdowsi University of Mashhad, Mashhad, Iran \\ 3. Professor of Department of Biology, Faculty of Sciences, Ferdowsi University of Mashhad, Mashhad, Iran \\ 4. Associate Professor of Department of Electrical Engineering, Faculty of Engineering, Ferdowsi University of Mashhad, Mashhad, Iran \\ 5. Assistant Professor of Department of Statistics, Faculty of Mathematics Sciences, Ferdowsi University of Mashhad, Mashhad, Iran
}

Recieved: 4 Apr. 2018

Revised: 17 Dec. 2018

Accepted: 20 Dec. 2018

\section{Keywords}

Event related potentials (ERPs)

Conceptual and procedural knowl-

edge

Interpretation of the graph of function

Cognitive performance

\section{Corresponding author}

Hassan Alamolhodaei, Professor of Department of Mathematics Education, Faculty of Mathematical Sciences, Ferdowsi University of Mashhad, Mashhad, Iran

Email: Alam@um.ac.ir

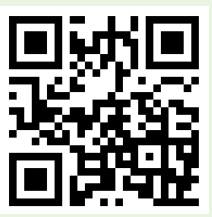

doi.org/10.30699/icss.21.4.46

\section{Abstract}

Introduction: The purpose of this study is to compare the cognitive processes and abilities of two groups of students by using and analyzing event-related potentials (ERPs) during solving problems on interpretation of the graph of functions.

Methods: The research method was quantitative and quasi-experimental. The participants of this study were 177 male undergrad engineering students. By the researcher-made mathematics test, participants were divided into two groups of deep conceptual and procedural knowledge (DK) group and superficial conceptual and procedural knowledge (SK) group. Fourteen students were randomly chosen from each group and taken the task and ERPs recording experiment.

Results: The DK group responded more accurately than the SK group. However, the reaction time of the two groups did not show significant variations. The ERP findings demonstrated that the amplitude of the P300 component for the SK group was considerably higher than that of the DK group over central, centro-parietal and parietal brain areas at the question window.

Conclusion: Although behavioral data in the reaction time of between two groups was almost identical, electrophysiological data indicated that doing the interpretation tasks in the SK group would have higher demands and activated further processing brain resources. Also, according to ERPs data, it was determined that the difference between the cognitive processing of the two groups occurs in the first stage and after seeing the graph of the function. These results point to the crucial role of cognitive neuroscientific technics in providing information on the differences in the cognitive performance of different individuals.

Citation: Farsad N, Alamolhodaei H, Moghimi A, Moghimi S, Jabbari Nooghabi M. A comparative study of cognitive processes in students with deep versus superficial knowledge on interpreting graphs of mathematical functions based on Event-Related Potential. Advances in Cognitive Sciences. 2020;21(4):46-57. 
())

\title{
مقايسه يردازش شناختى دانشجويان با دانش عميق و سطحى در حل مسائل تفسير نمودار تابع رياضى: يك مطالعه يتانسيل وابسته به رويداد
}

نجمه فر ساد'، سيد حسن عله الهدايى ז"(D) ، على مقيمى"، سحر مقيمى"، مهدى جبارى نوقابىه

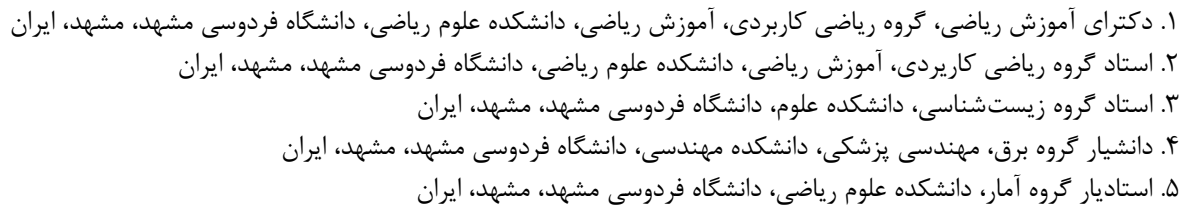

\section{ars}

\begin{abstract}
مقدمه: مطالعات رفتارى قبلى، فهم سطحى فراكيران از تابع و مباحث مرتبط با آن را عاملى موثر در مشكلات مربوط به حل مسائل تفسير نمودار تابع مىدانند. هدف اين مطالعه بررسى اين موضوع با استفاده از ابزار علوم اعصاب شناختى بود. بدين منظور يردازش هاى شناختى دو گروه از دانشجويان با دانش عميق و سطحى از تابع، هنحام حل مسائل تفسير نمودار تابع، با استفاده از يتانسيلهاى وابسته به رويداد (ERP) مقايسه شد. روش كار: اين يزوهش كمى و به روش نيمه تجربى بود. جامعه آمارى IVV نفر از دانشجويان رشتهاى مختلف مهندسى يكى از دانشخاههاى شرق كشور بودند كه توسط يك آزمون رياضى به دو كروه تقسيمم شدند: افراد داراى دانش مفهومى و رويهاى عميق و سطحى (دانش عميق و دانش سطحى). از هر كروه \&l نفر در آزمايش ERP شركت كردند. يافته ها: داده هاى رفتارى دقت پاسخ گروه دانش عميق را به طور معنادارى بالاتر از زروه دانش سطحى نشان داد. اما سرعت ياسخ دو گروه تفاوت معنادارى با يكديكر نداشت. دادههاى الكتروفيزيولوزى مشخص كرد كه دامنه مؤلفه P300

كروه دانش سطحى، در الكترودهاى نواحى مركزى، مركزى_آهيانهاى و آهيانهاى، بيشتر از گروه دانش عميق است. نتيجه گيرى: آر خه دادههاى رفتارى سرعت پاسخ دو گروه را تقريبا يكسان نشان داد، اما دادهاى الكتروفيزيولوزى مشخص كرد كه انجام تكاليف تفسير نمودار تابع، براى گروه دانش سطحى، خواستههاى توجهى بالاترى داشته و منابع يردازشى بيشترى را فعال مى كند. اين نتايج، نقش مهمم ابزارهاى علوم اعصاب شناختى را در فراهم آوردن اطلاعات در مورد تفاوتهاى عملكرد افراد مختلف نشان مى دهد.
\end{abstract}

دريافت: اصلاح نهايى:

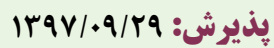
وازههاى كليلى يتانسيلهاى وابسته به رويداد دانش مفهومى و رويهاى تفسير نمودار تابع عملكرد شناختى

نويسنله مسئول سيد حسن علم الهدايى، استاد تروه رياضى كاريردى، آموزش رياضى، دانشكده علوم الهدي، استاد كروه رياضى رياضى، دانشخاه فردوسى مشهد، مشهد، ايران

ايميل: Alam@um.ac.ir

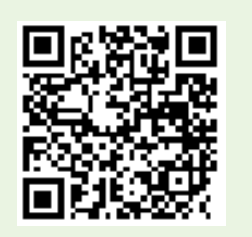

doi doi.org/10.30699/icss.21.4.46

مقلدمه

به اقداماتى كه توسط آن، فرد موفق به درك معنا يا مفهوم يك نمودار فراكير است (مانند مجلات، روزنامهها، تلويزيون و وبسايتها)، درى

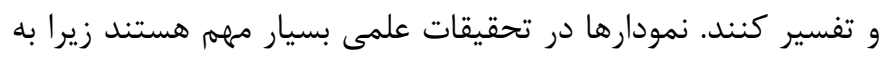
ميشود، تفسير نمودار كفته مىشود. اين اقدامات ميتواند در مورد

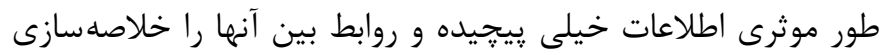
كل نمودار يا جزئى از آن باشد (1). تفسير نمودار، مهارتى بنيادى مى كنند و استفاده از آنها در كتابهاى درسى و علمى، نرمافزارهاى

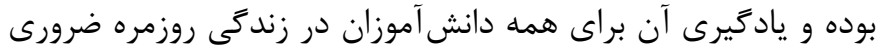

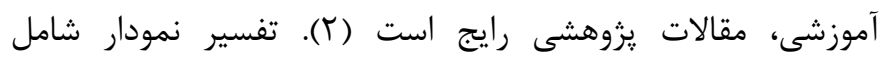

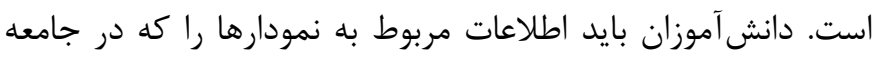


(1).. دانش رويهاى، نوع ديگرى از دانش و متشكل از الكوريتمها،

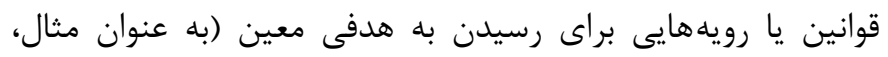

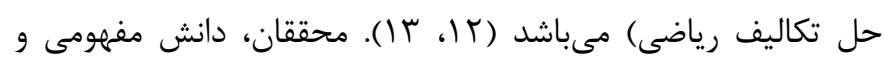

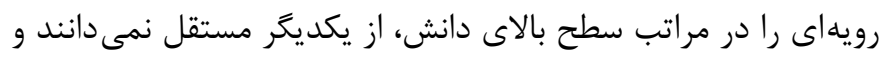

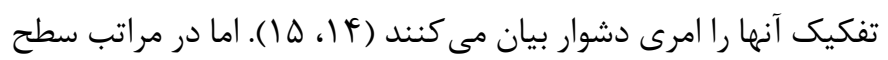

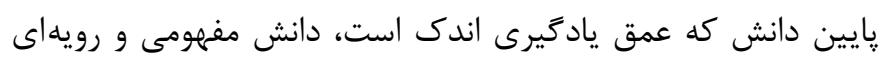

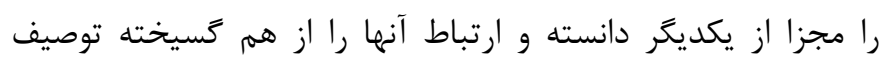

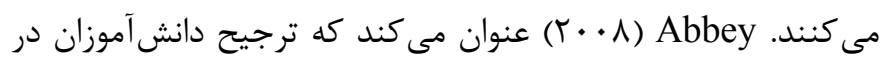

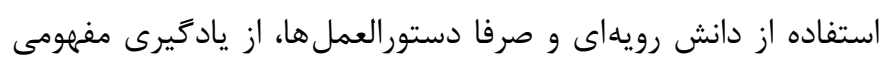
آنها جلوكيرى مى كند و اين عدم توازن بين دانش مفهومى و رويهاى،

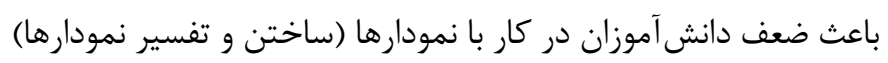

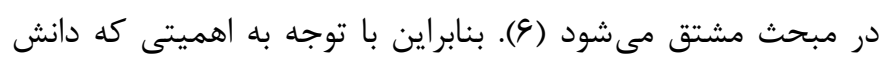

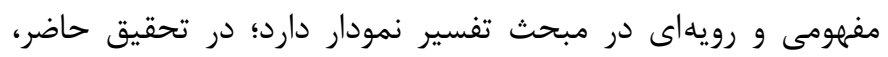

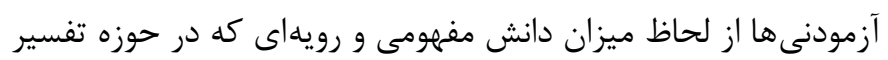
نمودار تابع دارند، تفكيك شدند. براى بررسى دقيقتر نقش دانش مفهومى و رويهاى افراد بر تفسير نمودار

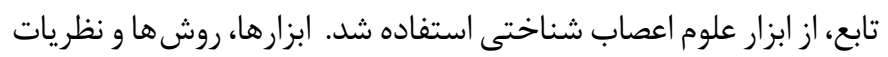

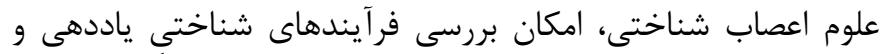

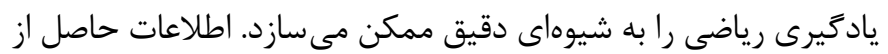

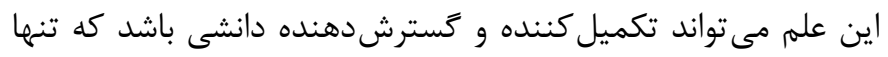

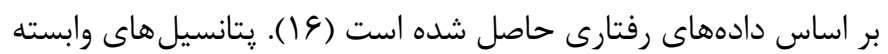

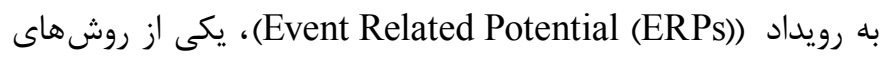

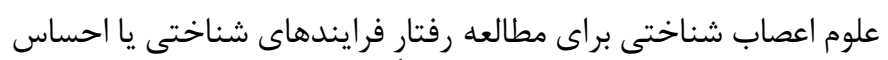

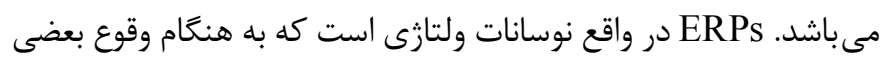

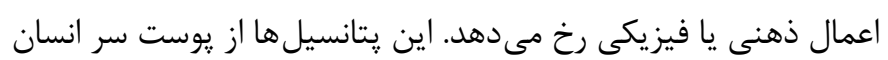

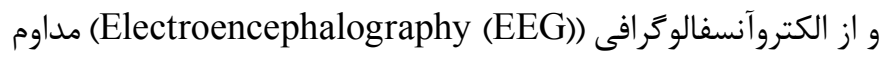
ثبت و توسط فيلتر كردن نويزها و ميانكَين كيرى كردن سيخنالها حاصل مىشود (IV). با بررسى رفتار اجزاى ERP مانند دامنه، تأخير

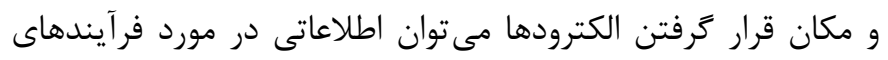

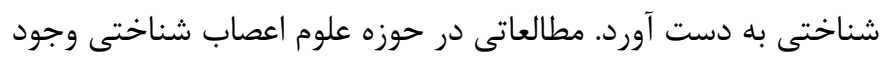

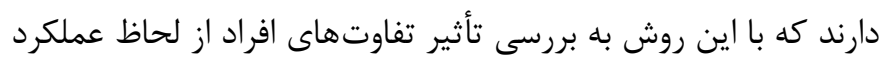

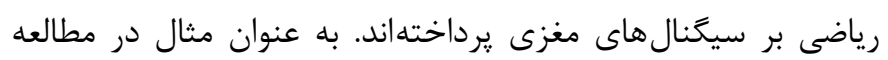
Nunez-Pena

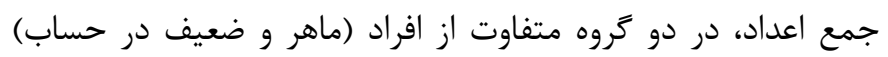

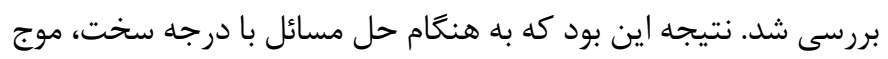

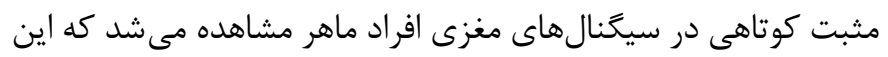

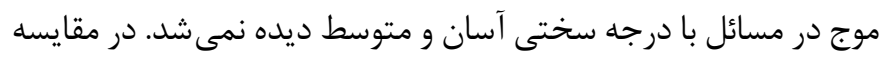

مهارتهاى مختلفى مانند، توانايى استخراج اطلاعات در مورد نقاط

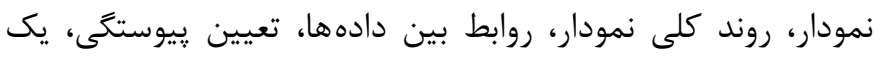

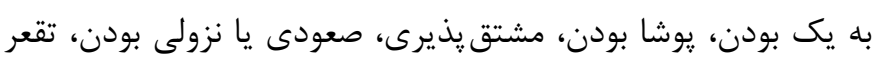

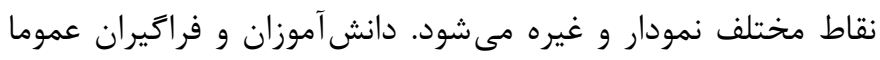

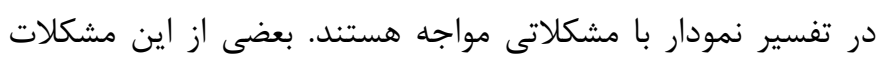

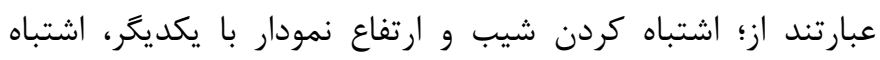

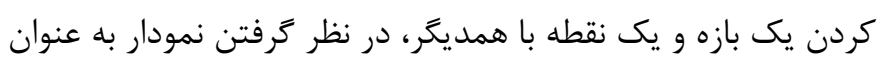

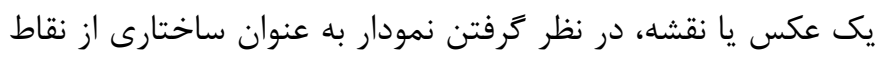

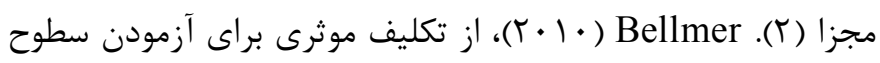

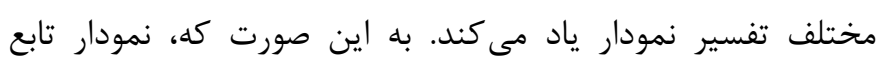

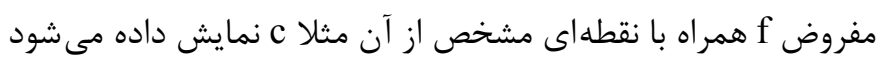

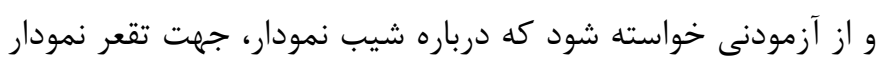

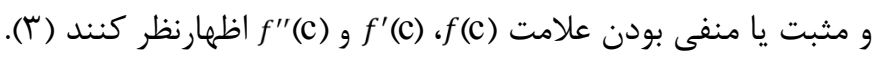

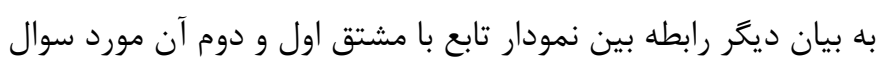

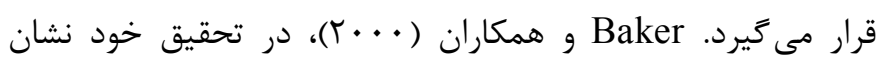

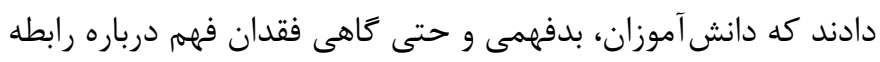

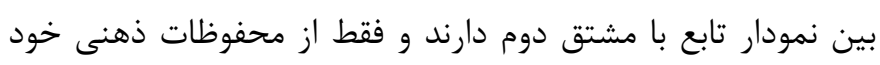

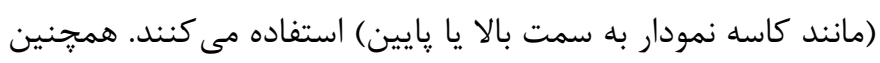

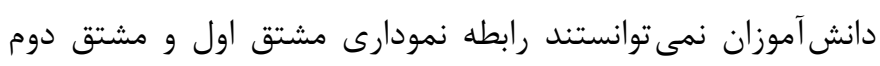

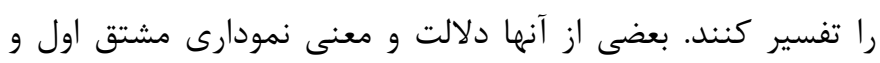

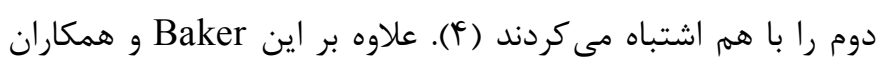

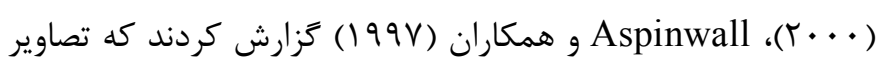
ذهنى غلط، باعث شده بود كه برخى دانش آموزان درباره توابعى كه

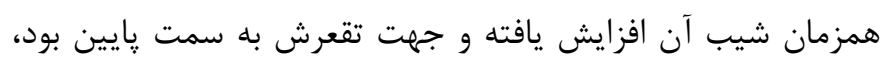

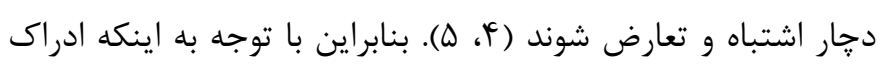

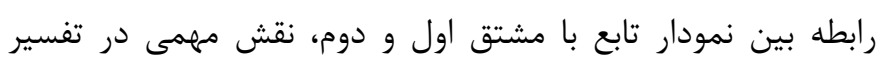

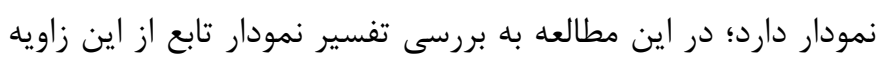

يرداخته شد. يكى از عوامل شناختى تأثيركذار در تفسير نمودار تابع، دانش قبلى شنى

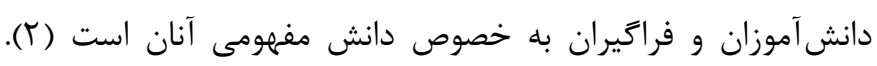

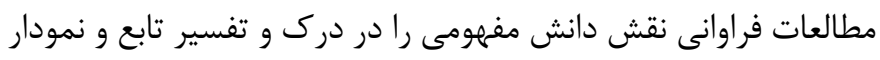

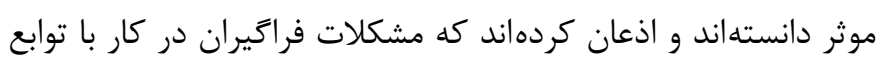

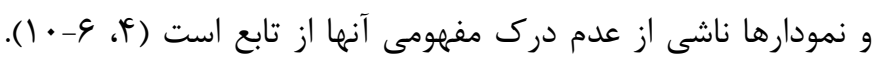

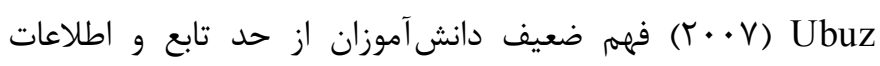

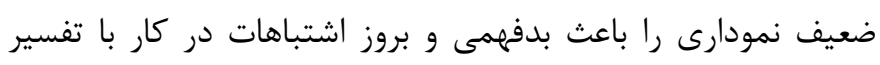

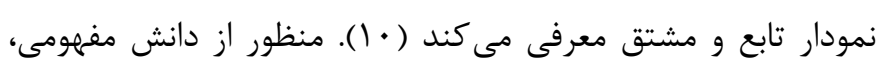

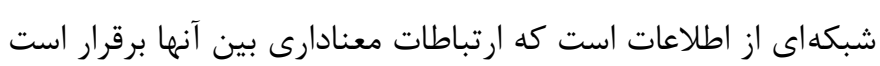


بيشتر از افراد داراى دانش سطح بالا در ينجره بازنمايى نمودارى است. بنابراين نتيجه گيرى شد كه خواستهاى ادراكى بازنمايى

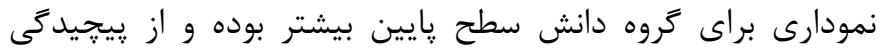
بيشترى برخوردار است. لذا ادعا شد كه راهبرد حل مسائل انتقال

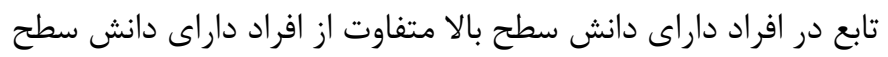

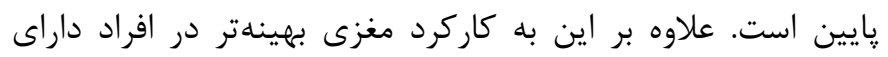

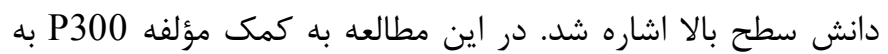
مقايسه يردازشهاى شناختي افراد داراى دانش مفهومى و رويهاى عميق و سطحى در حوزه تفسير نمودار تابع يرداخته شد.

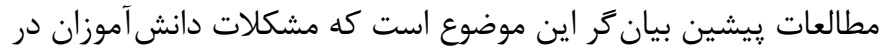
تفسير نمودار تابع، ناشى از حفظٍ بدون درك رويه ها مىباشد. بنابراين

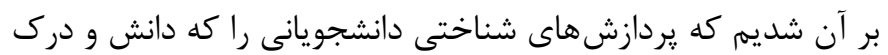
عميق و سطحى در حوزه تفسير نمودار تابع دارند، بررسى نماييم.

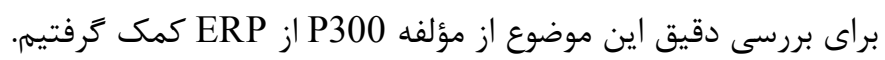

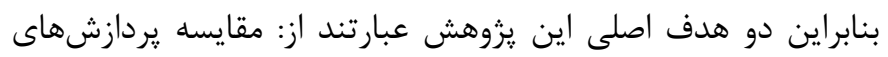

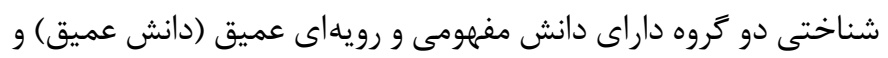

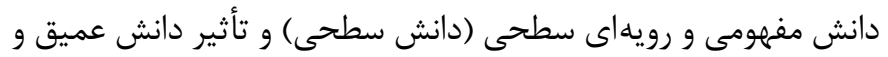
سطحى افراد در حل مسائل تفسير نمودار تابع. با توجه به مطالعه قبلى

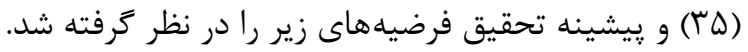
دقت و سرعت پاسخهاى درست دانشجويان با دانش عميق، نسبت به دانشجويان با دانش سطحى، بيشتر مىباشد.

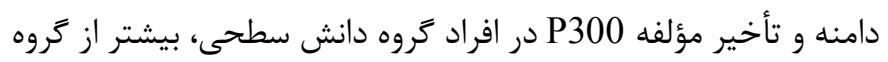
دانش عميق، در ينجره سوال است.

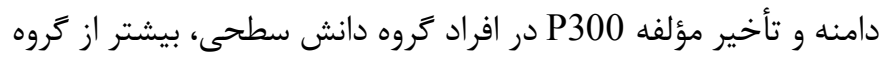
دانش عميق، در ينجره پاسخ است. همجنين قصد داريم مقايسهاى توصيفى بين نتايج تحقيق قبلى (ه山) و تحقيق حاضر انجام دهيم.

\section{روش كار}

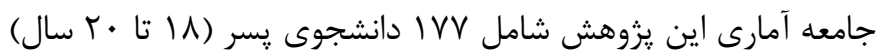

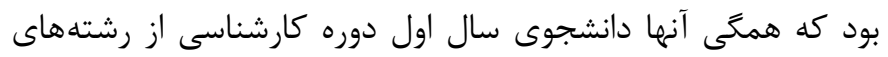

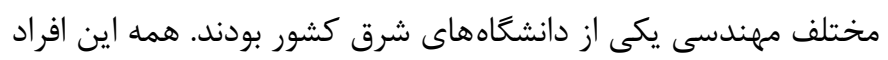

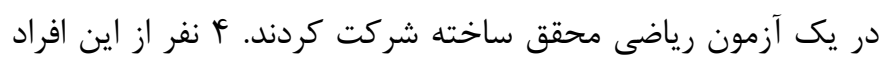

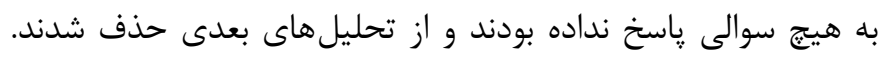

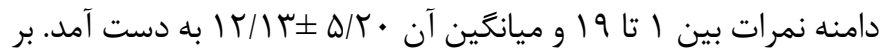
اساس ميانگين نمرات، افراد جامعه به دو دسته تقسيهم شدند، افرادى كه نمره بالاتر از ميانگين داشتند؛ در گروه دانش عميق و افرادى كه نمره
با افراد ماهر، اين موج در افراد ضعيف، هم به هنگًام حل مسائل با درجه سخت و هم مسائل با درجه متوسط اتفاق مىافتاد. بنابراين محققان اين مطالعه نتيجه گيرى كردند كه راهبردهايى كه افراد ماهر در حل مسائل اتخاذ مى كنند متفاوت از راهبردهاى افراد ضعيف است. محققان اين

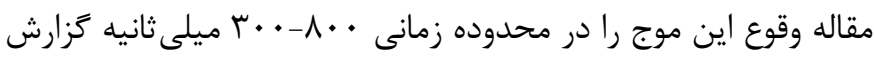

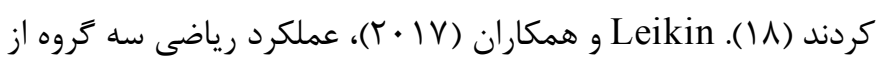
دانش آموزان را بررسى كردند. گروه اول افراد فوق العاده با استعداد در رياضيات (S-MG) بودند. گروه دوم افرادى كه عملكرد رياضى خوب و بهره هوشى بالاتر از • سا (G-EM) داشتند. گروه سوم افرادى كه داراى عملكرد رياضى خوب اما بهره هوشى يايينتر از • با بودند (NG-EM) نتايج نشان داد كه در كل ميانگين دامنه ERP در افراد گروه S-MG كمتر از دو گروه ديكر بود. همجنين فعاليت الكتريكى مغز افراد گروه G-EM كمتر از گروه NG-EM بود، كه بيان اين موضوع است افرادِ با بهره هوشى بالاتر، كاركرد مغزى بهينه ترى

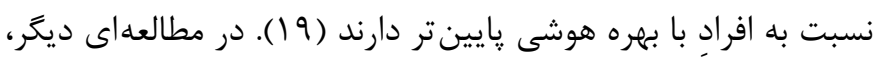
و همكاران (Faisman افراد را بر حل مسايل بازنمايى تابع مورد بررسى قرار دادند. آنها نشان دادند كه دامنه مؤلفه P300 در افرادى كه عملكرد رياضى خوب و بهره هوشى بالاتر از • rا دارند، نسبت به افرادى كه عملكرد رياضى خوب اما بهره هوشى يايينتر از • با دارند، كمتر است. بنابراين نتيجه گرفتند كه افراد با بهره هوشى يايينتر، منابع ذهنى بيشترى را براى توجه به تكليف و يردازش آن اختصاص مى دهند ( • P). مؤلفه مثبتى از ERP است كه قله (Peak) آن حدودا . . بـ ميلى ثانيه يا بيشتر (حداكثر . ㅇ ميلى ثانيه) بعد از ارائه محرك نمايان مىشود

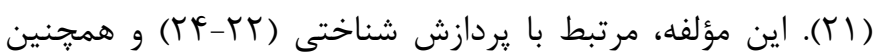
يردازش هاى شناختى مرتبه بالاتر مثل طبقهبندى و ارزيابى محرى

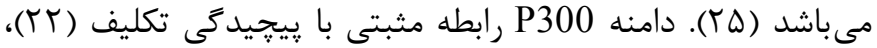

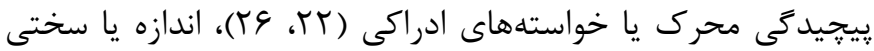

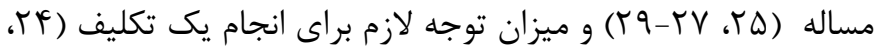
• r، (Y) دارد. همجنين وابسته به ماهيت موضوع (rr) و انتخاب

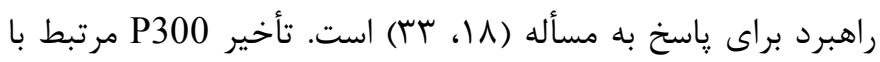

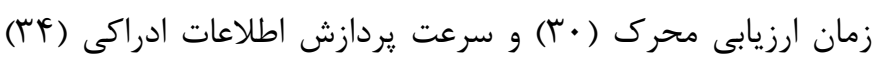
در مطالعه قبلى نويسندكان اين مقاله (هऍ) به مقايسه دامنه مؤلفه P300 دو گروه از دانشجويان با دانش مفهومى و رويهاى سطح بالا و سطح يايين، بر عملكرد رياضى در حوزه انتقال تابع يرداخته شد. نتايج نشان داد كه دامنه مؤلفه P300 افراد داراى دانش سطح پيايين 
قرار دادن تعريف عملياتى زير طراحى شد. الداشتن فهم و ادراك از مفاهيم، توانايى تفسير قوانين و الكوريتمها، انعطافيذيرى در به كارگيرى رويهها، انتخاب و انجام مناسب

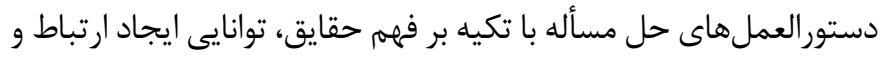

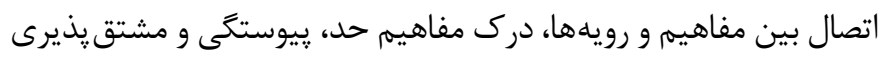

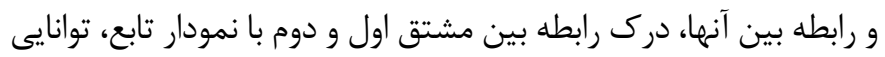

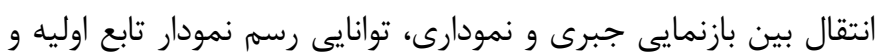

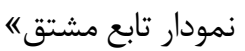

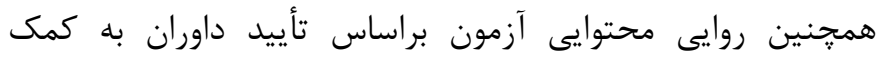
يرسشنامه از •r داور سنجيده شد (TV). اين داوران، معلمان

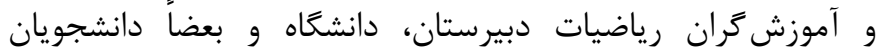
تحصيلات تكميلى آموزش رياضى بودند. شاخص روايى محتوايى يعنى (Content validity coeficient (CVC) (براى اطلاعات

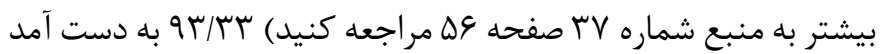

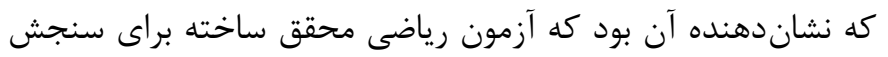
دانش مفهومى و رويهاى افراد در زمينه مورد نظر "بسيار مطلوبه است.

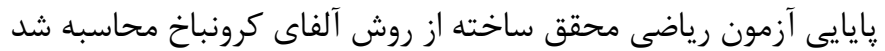
و مقدار آن هو • به دست آمد. محرك: محرك ها متشكل از دو ينجره مجزاى "اسوال" و "پاسخخ" بودند. در קنجره سوال، يك نمودار از توابع سهمى شكل با حالاتى مختلف (با توجه به قراركيرى مكان نمودار، شيب و جهت تقعر در نقطه (c) (c,f(c) و در پِنجره پاسخ، سه شرط همزمان در مورد مثبت يا منفى بودن

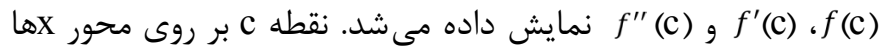
مشخص شده بود. محرك ها به رنگ مشكى روى زمينه سفيد و در مركز

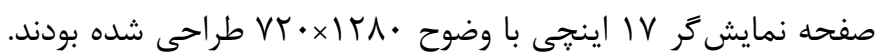

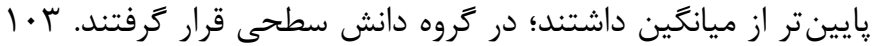

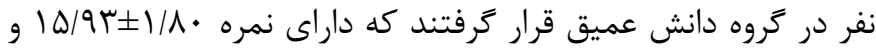

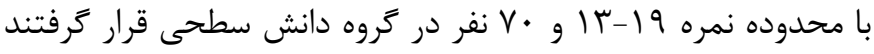
كه داراى نمره ه • / توسط نرمافزار PASS برآورد شد. به اين صورت كه با توجه به نتايج

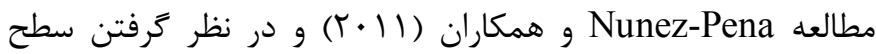

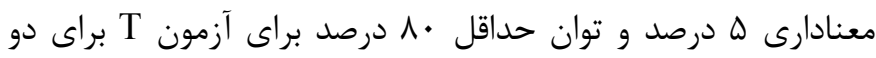

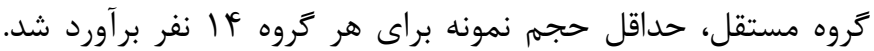
براى جلوگيرى در عدم ريزش بيش از حد در مرحله آزمايش اصلى،

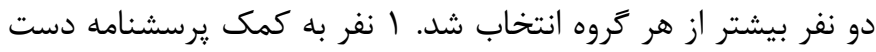
برترى ادينبورى (Edinburgh) هر دو دست شناخته شد و از آزمون

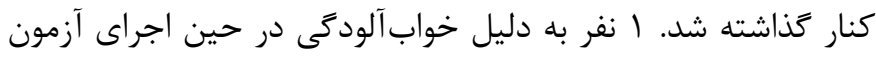

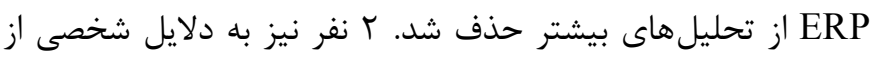

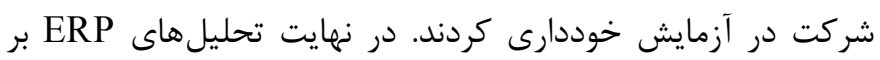

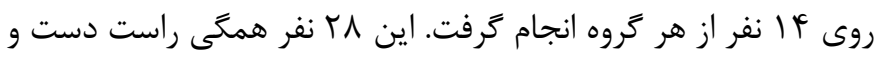

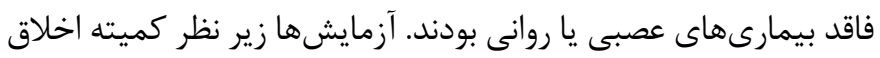

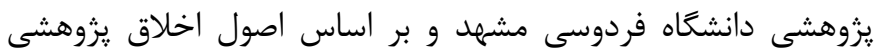
بين المللى انجام شد. همجنين به شركت كنندكان به خاطر شركت در

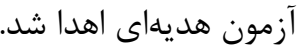

آزمون رياضى محقق ساخته: شركت كنندكان بر اساس يك آزمون آزدان رياضى به دو گروه دانش عميق و دانش سطحى در حوزه تفسير نمودار

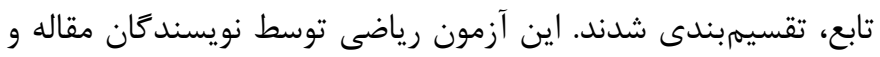
با كمك اساتيد، معلمان با تجربه و مقالات معتبر علمى مانند مقالات

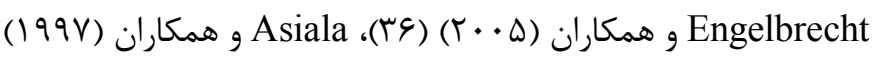
Baker و همكاران ( (Y)

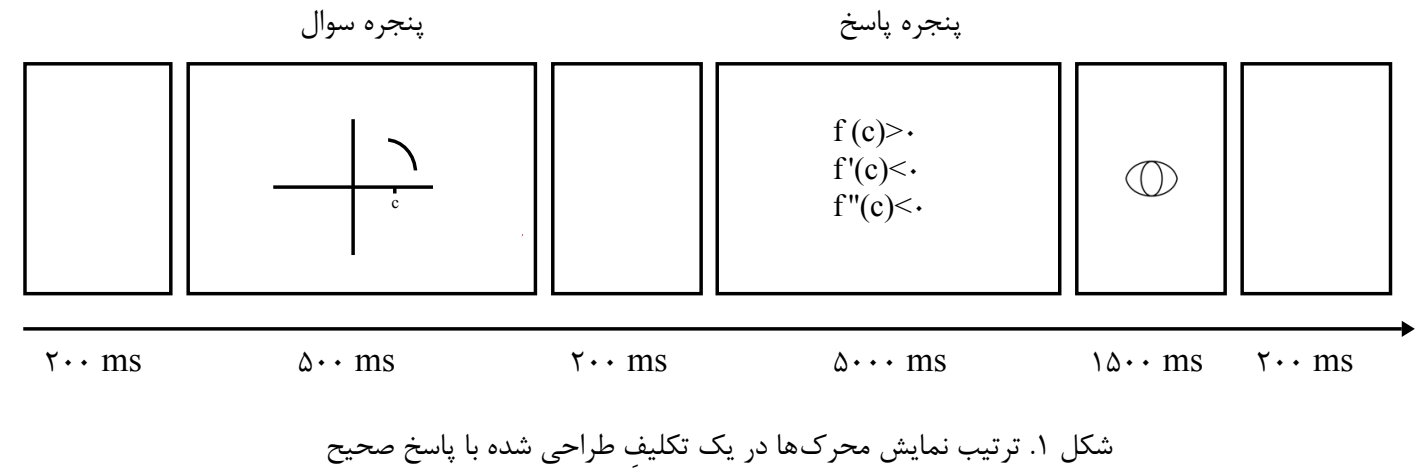

كوتاه بين بلوكها طراحى شده بود. هر تكليف از 9 ينجره تشكيل شده بود. اولين پنجره، صفحهاى سفيد با علامت + در وسط نمايش

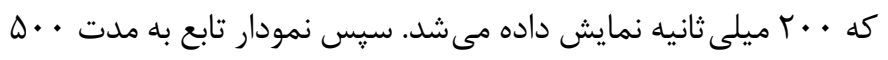

برنامه نمايش محركها به كمك نرمافزار MATLAB طراحى شده بود. دستور العمل: سوالات شامل · · ا تكليف، •ع تكليف غلط و • ع تكليف صحيح، بود. تكاليف به صورت ه بلوك • r تايى و يك زمان استراحت 


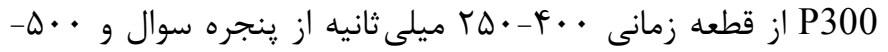

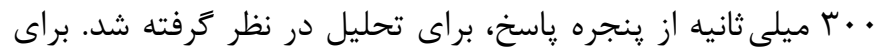

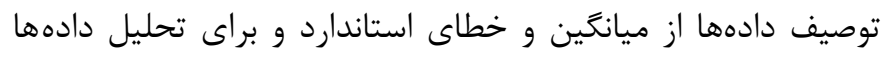

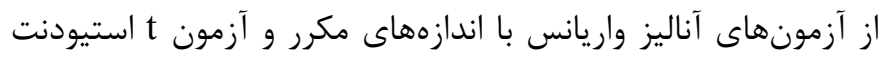

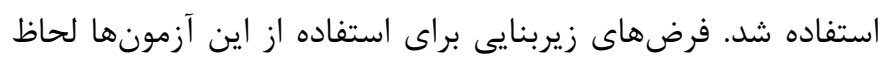

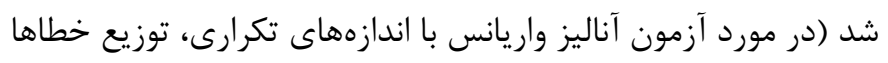

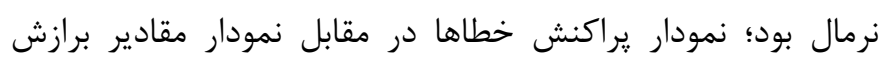

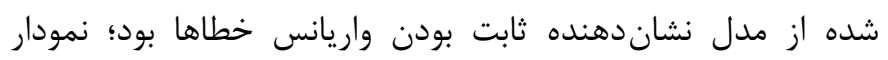

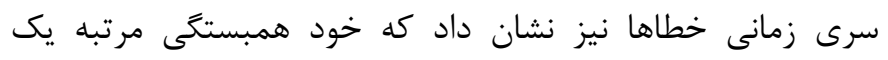

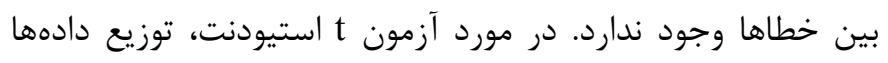

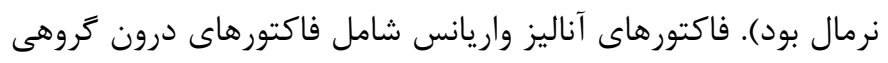

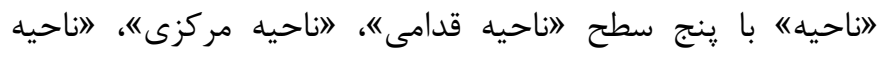

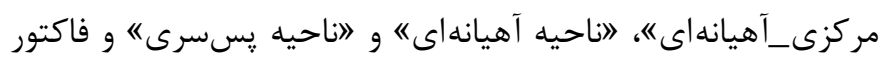

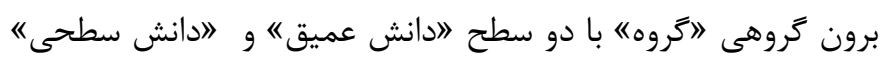

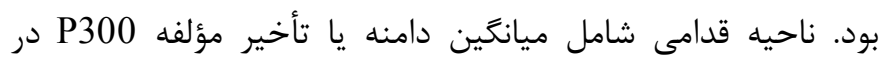

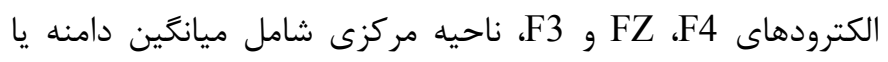

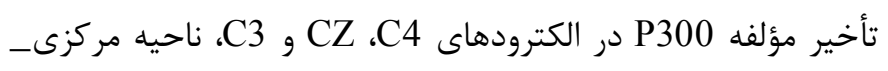

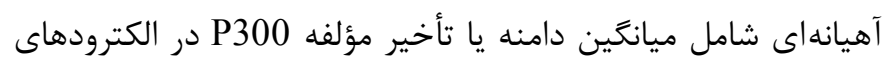

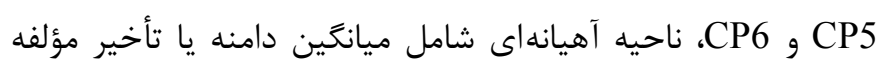

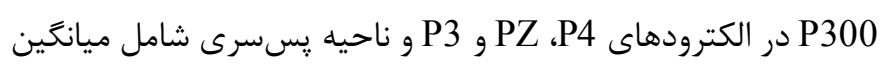

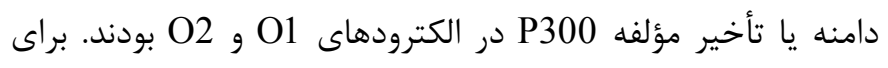

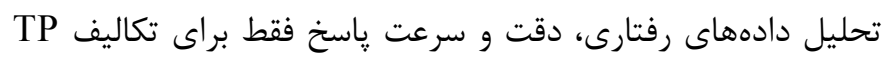

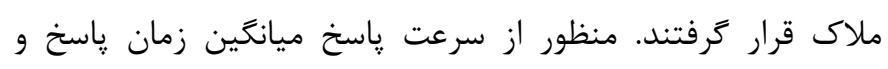

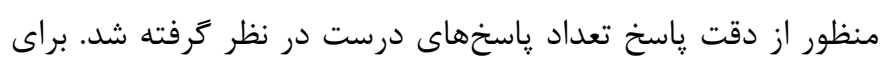

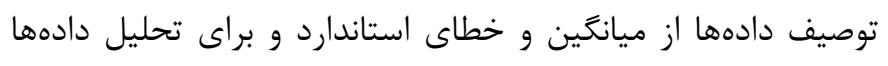

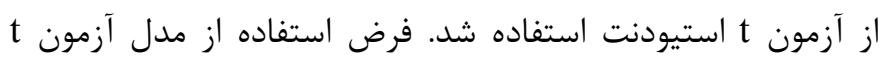
استيودنت برقرار بود (توزيع دادهها نرمال بود).

\section{يافته ها}

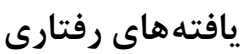

آزمون t استيودنت نشان داد كه تعداد پاسخهاى درى درست دانشجويان

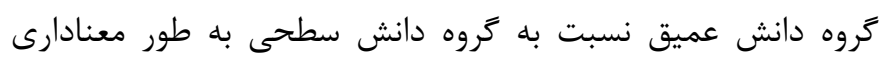

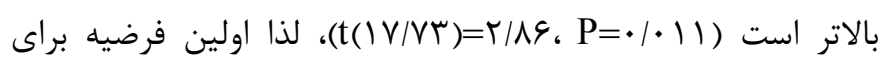

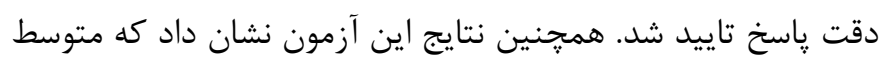

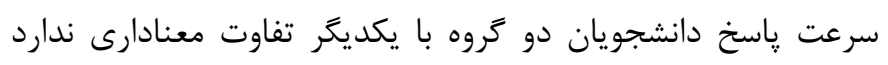

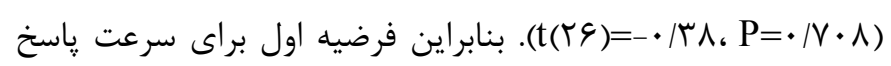

ميلى ثانيه نمايش داده شده (ينجره سوال)، بعد به مدت . . T ميلى ثانيه

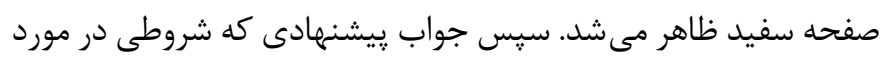

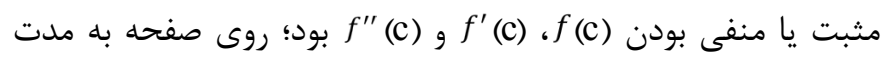

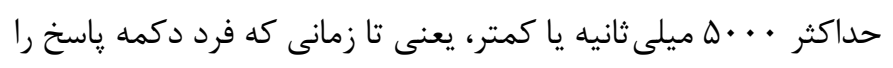

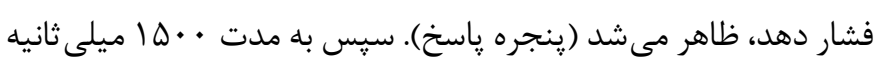

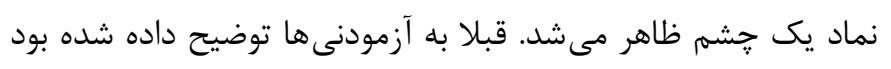

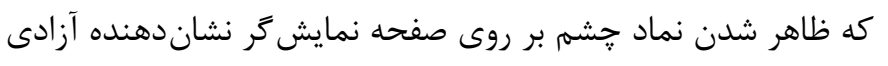

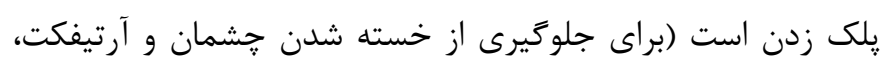

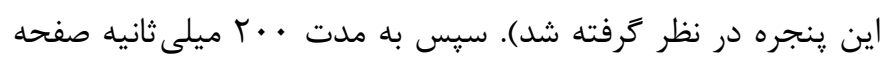

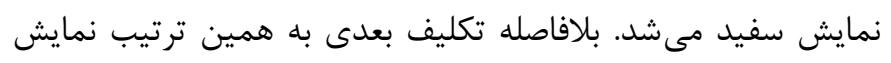

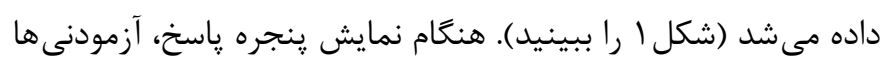

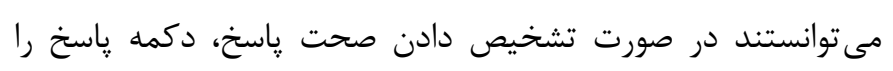

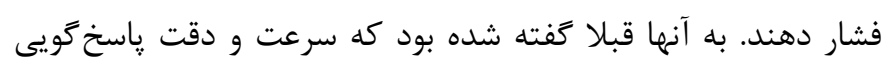
آنها محاسبه خواهد شد. تصند

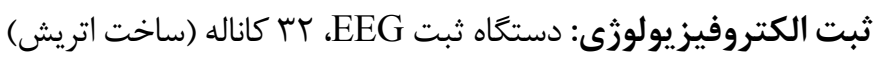
همراه با سا الكترود فعال روى كلاه ثبت (g.GAMMAcap, Austria)

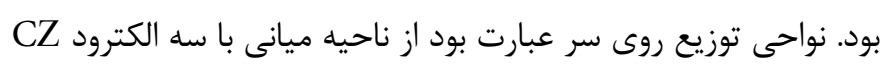

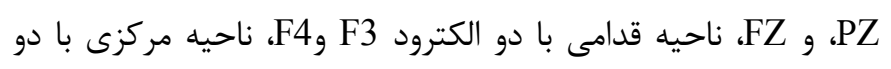

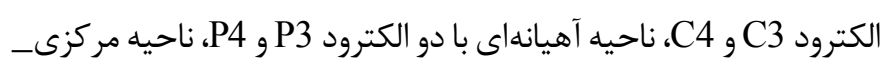

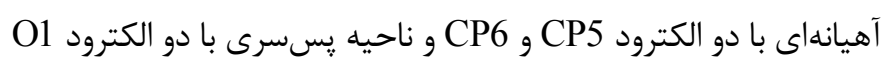

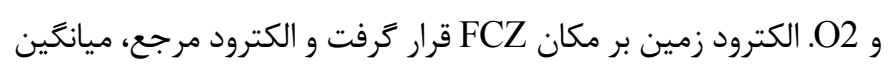

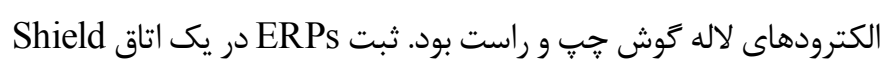

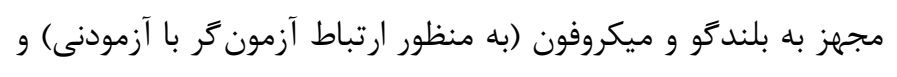

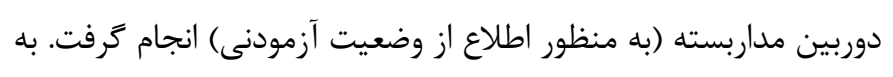

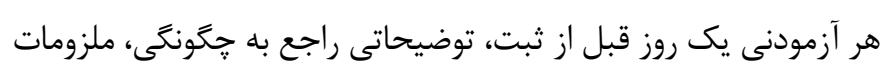

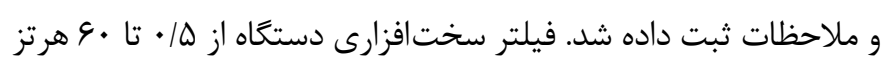

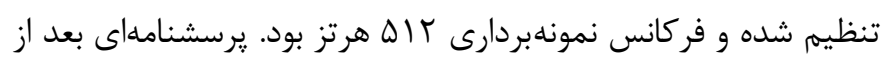

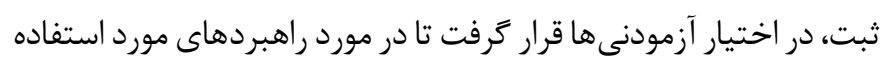
خود براى حل سوالات، توضيحاتى بنويسند.

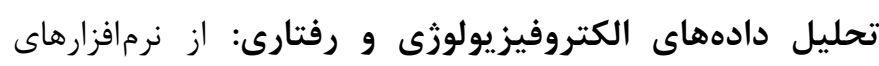

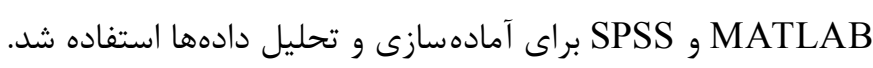
ينجرههاى زمانى سوال و پاسخ از تكاليف TP (تكاليفى كه پياسخ آنها

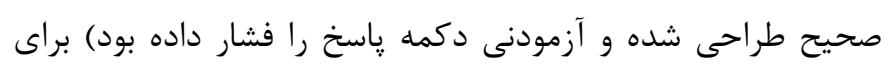

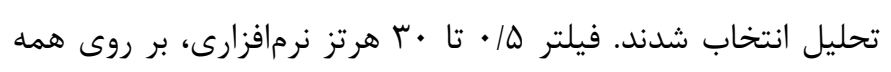

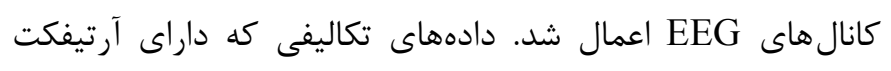

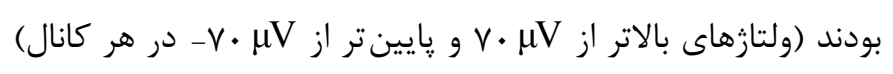
حذف شدند. از طريق مشاهده ERPs همه افراد، دامنه و تأخير مؤلفه 

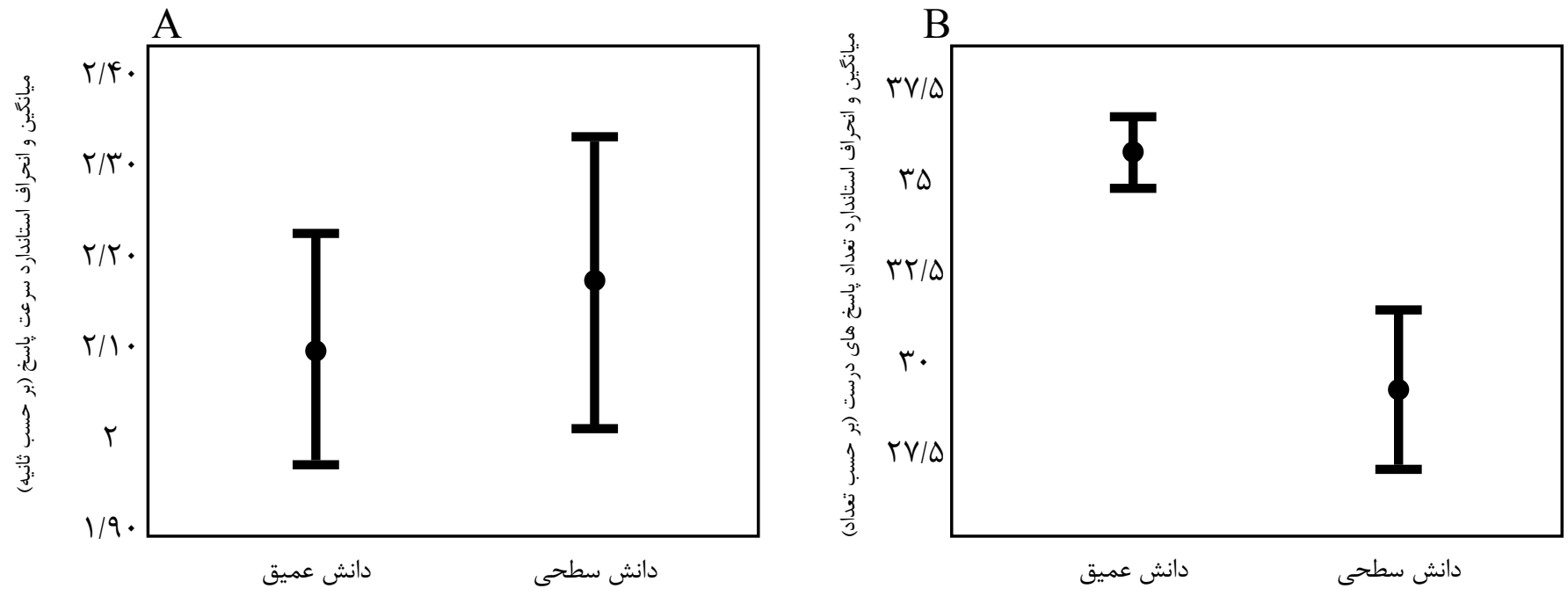

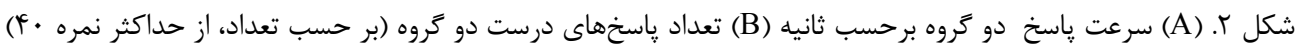

سوال انجام شد كه هيج كدام از فاكتورهاى ناحيه (F=•F/F

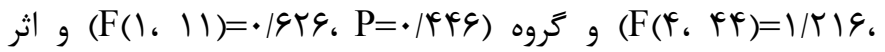

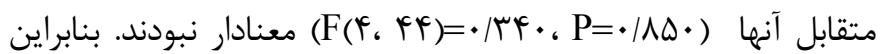

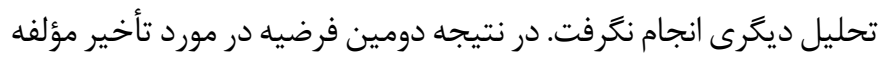

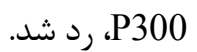

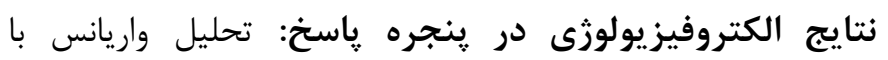

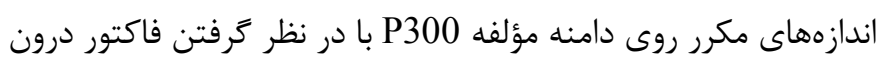

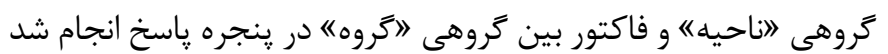

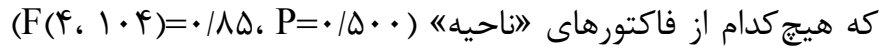

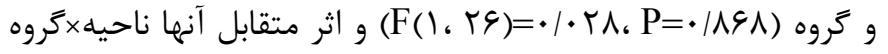

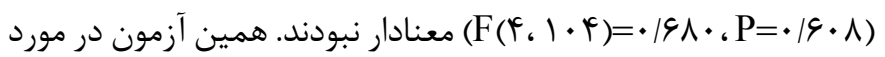

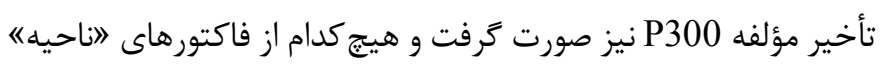

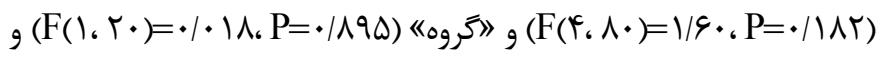

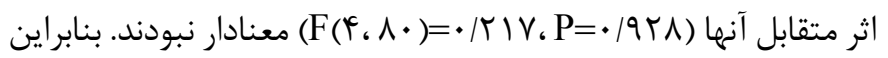
سومين فرضيه رد شد.
يافته هاى الكتروفيزيولوزى نتايج الكتروفيزيولوزى در ينجره سوال: با انجام تحليل واريانس با اندازههاى مكرر روى دامنه مؤلفه P300 در ينجره سوال مشخص شد كه

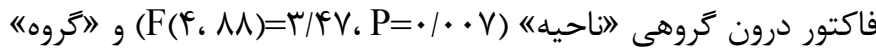

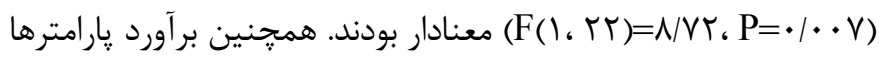

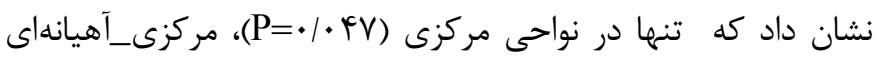

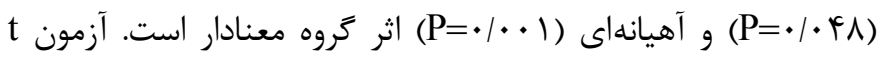
استيودنت براى هر كدام از اين نواحى انجام گرفت و مشخص شد كه آنه

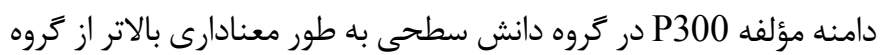
دانش عميق، براى هر كدام از اين ناحيهها مى باشد كه نتايج آن به طور

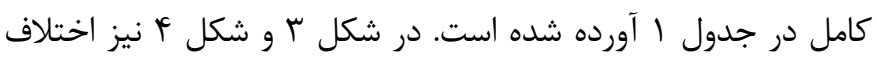
ميانكين دامنه مؤلفه P300 افراد كروه دانش عميق و دانش سطحى در الش درد

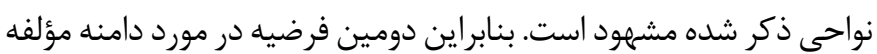
P300 براى ناحيه هاى مركزى، مركزى_آهيانهاى و آهيانهاى تأييد شد. تحليل واريانس با اندازههاى مكرر روى تأخير مؤلفه P300 در مركي رينجره

\section{جدول ا. ميانگين دامنه مؤلفه P300 در دو كروه دانش عميق و دانش سطحى (بر حسب}

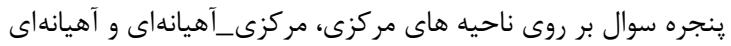

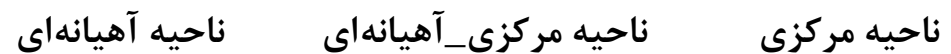

\begin{tabular}{|c|c|c|c|}
\hline$\mu / \cdot r$ & $r / 1)$ & $r / 9$. & ميانكين دامنه مؤلفه P300 در كروه دانش سطحى \\
\hline$\cdot / r \Delta$ & $\cdot / \Gamma \cdot$ & $\cdot|\Lambda|$ & ميانگَين دامنه مؤلفه P300 در كروه دانش عميق \\
\hline$t=-r / r V$ & $t=-r / r q$ & $\mathrm{t}=-r / r q$ & \\
\hline $\mathrm{df}=\mathrm{r}$ & $\mathrm{df}=r \mathrm{r}$ & $d f=r r$ & ن إيج آزمون t استودنت \\
\hline $\mathrm{P}<\cdot / \cdots 1$ & $\mathrm{P}=\cdot / \cdot r q$ & $\mathrm{P}=\cdot / \cdot r \Delta$ & \\
\hline
\end{tabular}



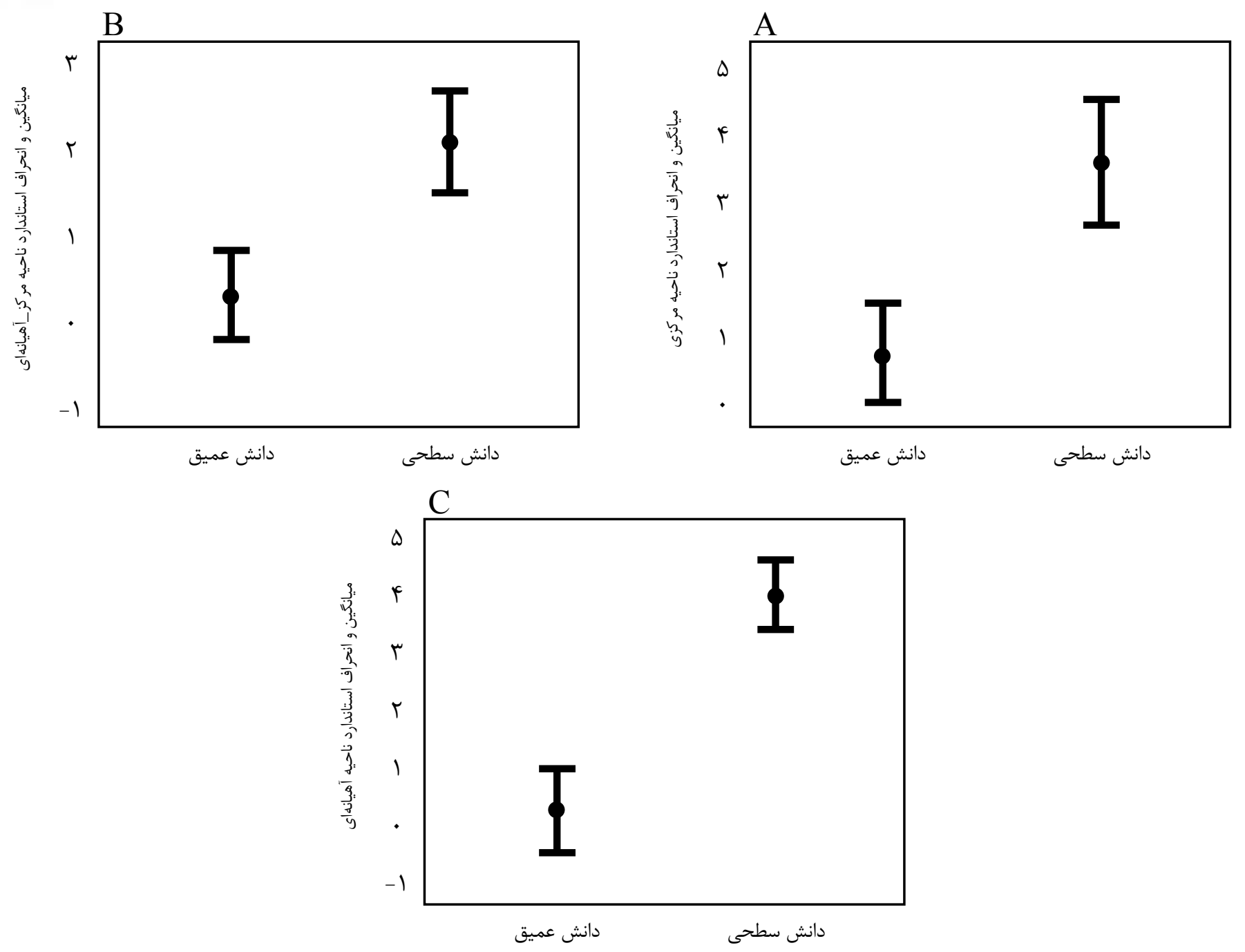

شكل r. ميانكَين و انحراف معيار دامنه مؤلفه P300 در دو كروه (بر حسب (بV) در نواحى مركزى (A)، مركزى_آهيانهاى (B) و آهيانهاى (C)
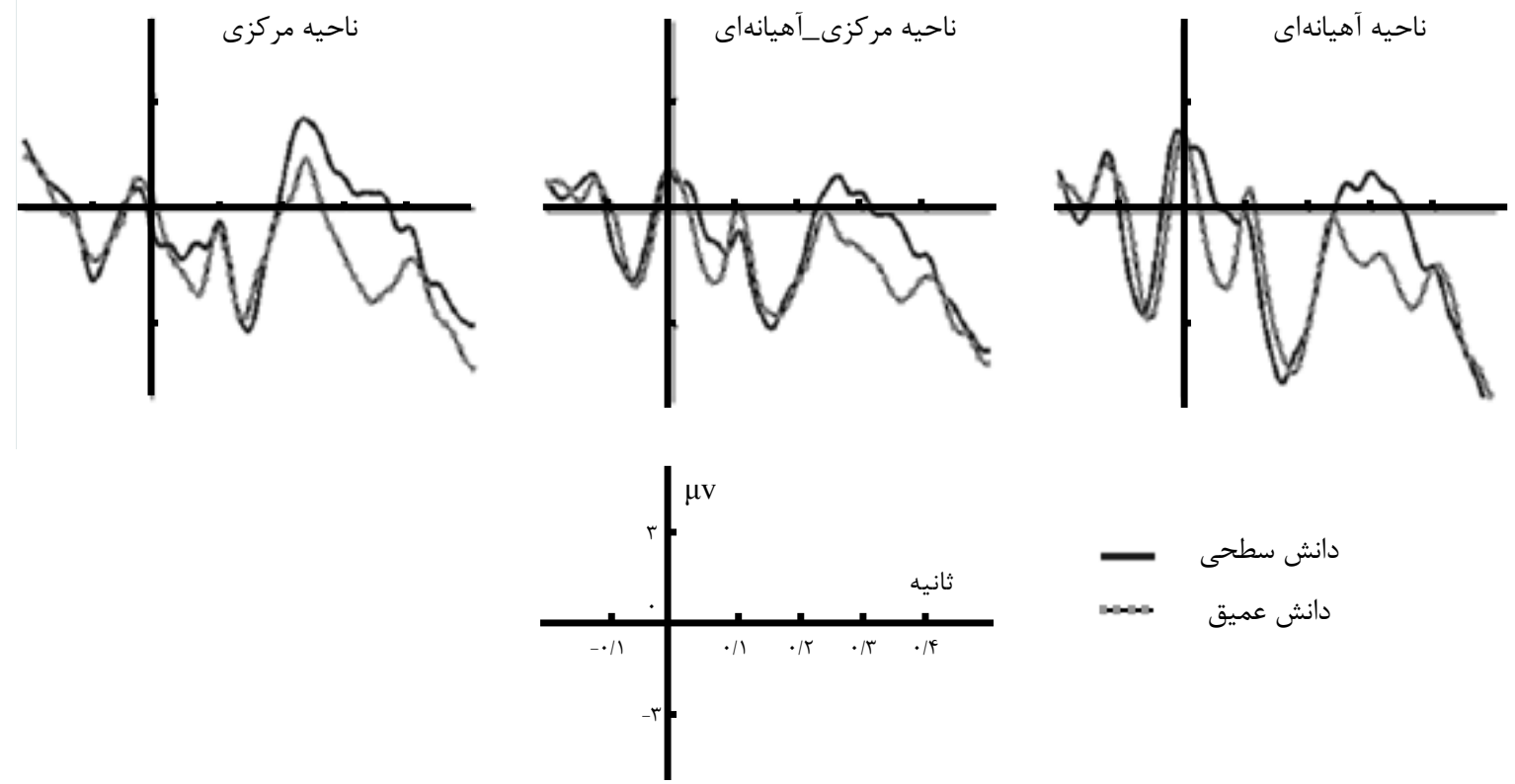

دانش سطحى

شكل F. ميانكين ERPs افراد كروه دانش عميق (F) أ نفر) و كروه دانش سطحى (F) نفر) در ينجره سوال در نواحى "مركزى"، "مركزى_آهيانهاى" و "آهيانهاى" مغز 
همه افراد گروه دانش عميق، به مفاهيم و رويههاى مبحث مورد نظر تسلط كافى دارند. تعدادى از افراد گروه دانش سطحى نيز به درستى

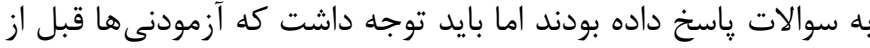
آزمايش ERP به كمك آزمون رياضى محقق ساخته به دو گروه تقسيم

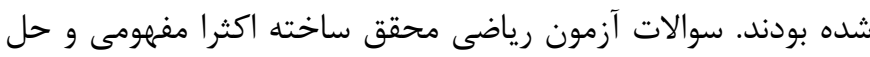
آنها مستلزم دانش عميق درباره مفاهيم و رويهها بود. بنابراين مى توان نتيجه كرفت كه اترجه برخى از افراد كروه دانش سطحى به درستى درانى

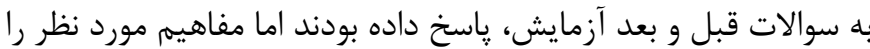
درك نكرده و رويهها را به صورت طوطىوار حفظ كرده بودند. نتايج رفتارى آزمايش ERP نشان داد كه دقت پاسخ در گروه دانش عميق به طور معنادارى بيشتر از گروه دانش سطحى است. اين نتيجه مورد انتظار بود زيرا با توجه به تعريف عملياتى كه براى كروه دانش عميق در نظر گرفته شده بود، ييشبينى مى شد كه تعداد باسخهاى درست افراد كروه دانش عميق بيشتر از افراد كروه دانش سطحى باشد.

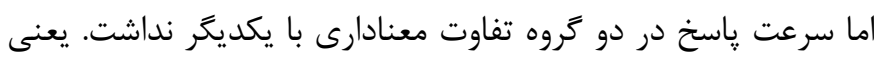

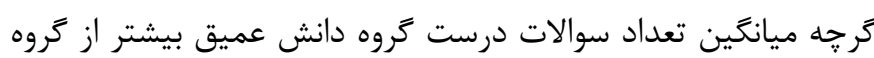
دانش سطحى بود اما آنها با سرعت تقريبا مشابه با كروه دانش سطحى، سوالات را ياسخ داده بودند. توجيهى كه مى توان براى اين نتيجه عنوان كرد اين است كه افراد با توانايى بالاتر نسبت به افراد با توانايى يايينتر تمايل بيشترى به بالابردن زمان ياسخ به نفع افزايش تعداد پاسخهاى

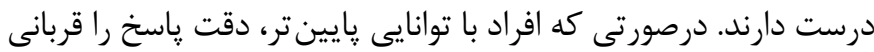

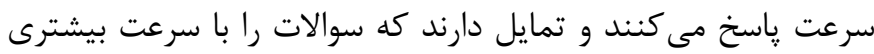

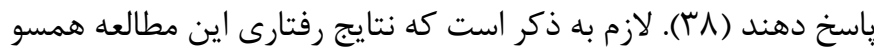
با مطالعه قبلى نويسندكان بود (ها). در مطالعه قبلى نيز افرادى كه

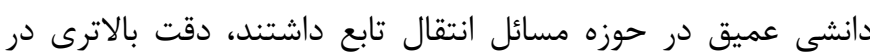
حل مسائل نسبت به افراد داراى دانش سطحى نشان دادند. اما سرعت داليق باستخشان با يكديخر تفاوت معنادارى نداشت. تحليل بر روى دادهاى الكتروفيزيولوزى در دو ينجره زمانى سوال

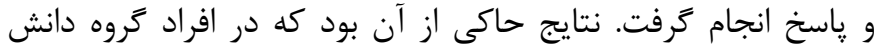
سطحى، دامنه مؤلفه P300، بر روى ناحيههاى مركزى، مركزىــ

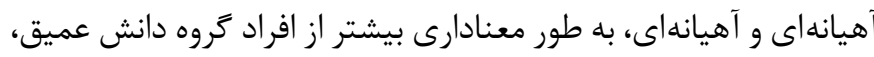

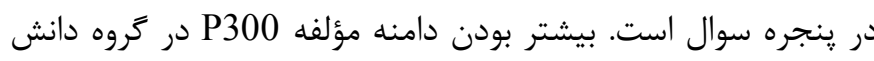

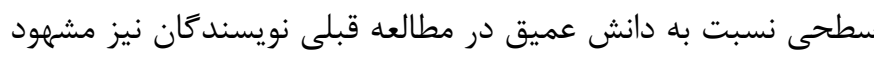
بود. مى توان اين نتيجه را به اختصاص منابع يردازشى كمتر و كاركرد مغزى بهينهتر براى حل تكاليف تفسير نمودار، در افراد گروه دانش

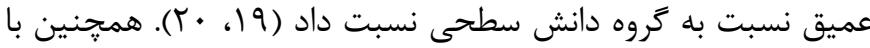
توجه به ارتباط مثبت بين دامنه مؤلفه P300 با ميزان توجه، مى توان
يافته هاى حاصل از يرسشنامه

قبل از شروع آزمايش از آزمودنىها خواسته شد كه به اين سوال ياسخ

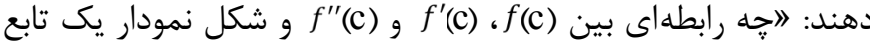
در نقطه c وجود دارد؟؟ تمام افراد گروه دانش عميق ياسخ درست به سوال دادند اما تنها 9 نفر از گروه دانش سطحى ياسخ درست دادند و

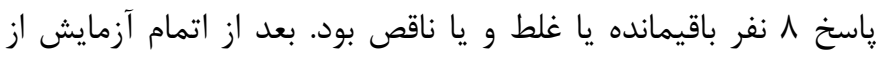
آزمودنى ها خواسته شد كه عنوان كنند تا جه حد به سوالات تصادفى لإنى ياسخ دادهاند. 1 نفر از گروه دانش عميق گز ينه خيلى كم و و نفر كزينه كم را علامت زدند. ₹ نفر از گروه دانش سطحى گز ينه خيلى كم و 1 نفر كزينه كم و ץ نفر گزينه متوسط را علامت زدند. در קاسخ به سوال "ابه جه ويزگى هايى از نمودارها براى يافتن جواب درست توجه مى كرديد؟ همه آزمودنى هاى كروه دانش عميق به هر سه ويزگى مكان، شيب و جهت تقعر نمودار اشاره كرده بودند. V نفر از گروه دانش عميق به هر

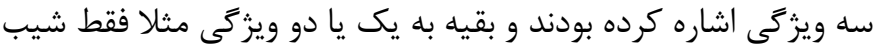
و مكان نمودار يا شيب و جهت تقعر يا فقط شيب نمودار اشاره كرده

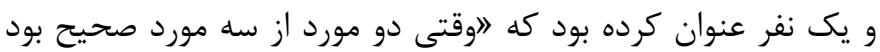

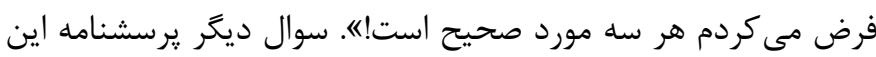

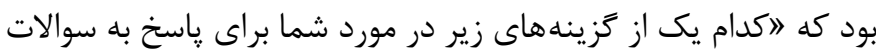
صدق مى كند؟ الف) به محض اينكه نمودار تابع را ديدم قبل از آنكه صفحه جواب ظاهر شود، جواب را در ذهنم يافتم. ب) من سعى كردم تصويرى از نمودار را در ذهنم نكاه دارم و بعد از ديدن جواب روى صفحه نمايش

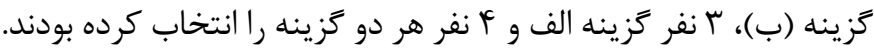

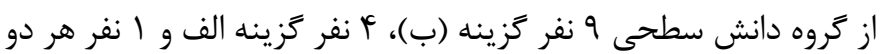
كزينه را علامت زده بودند.

اهداف اين مطالعه، مقايسه يردازشهاى شناختى دو گروه مختلف از

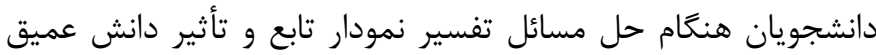

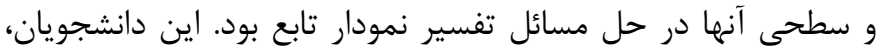
داراى دانش مفهومى و رويهاى عميق و سطحى در مبحث تفسير نمودار تابع در حوزه مشتق بودند. براى نيل بهتر به اين هدف از ابزار استفاده شد و دادهاى رفتارى و الكتروفيزيولوزى مورد تحليلهاى داى دائ آمارى قرار كَرفت. همجنين قبل و بعد از اتمام آزمايش، از آزمودنىها سوالاتى درباره ادراك آنها از رابطه بين نمودار تابع و مشتق اول و دوم و راهبردهاى مورد استفاده براى ياسخ كويى به سوالات يرسيده شد. نتايج حاصل از يرسشنامه قبل و بعد از آزمايش، حاكى از آن بود كه 
يافتههاى آنان باشد. زيرا اول، مشخص شد كه افراد داراى دانش عميق از دقت بالاترى در حل مسائل تفسير نمودار برخوردارند. يعنى دانش عميق باعث عملكرد بهتر افراد در حل مسائل تفسير نمودار تابع شد. دوم، با

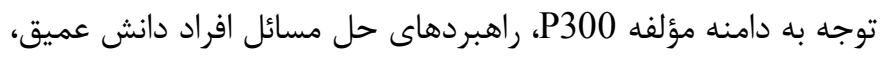

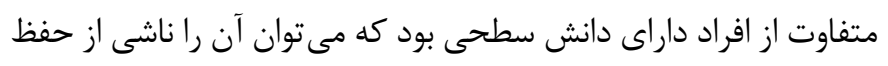

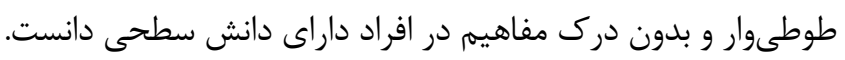

\section{نتيجه گیرى}

در مجموع با توجه به نتايج يرسشنامه و نتايج رفتارى و الكتروفيز يولوزى

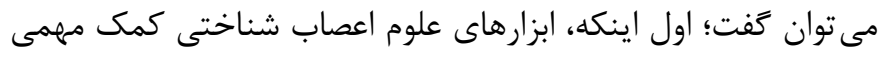
در تشخيص تفاوتهاى فردى در عملكرد رياضى ايفا مى كنند. دوم

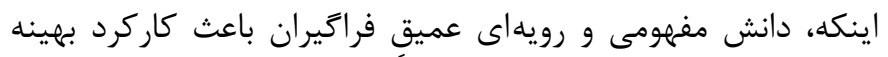

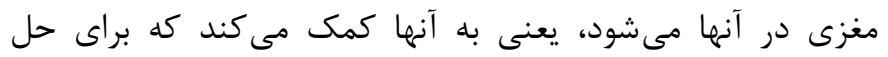

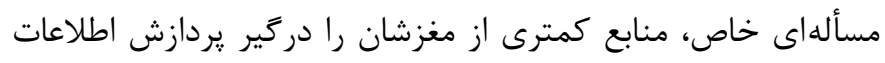

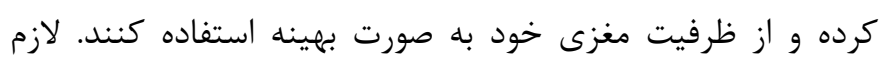
به ذكر است كه مشابه اين نتايج در تحقيق قبلى نويسندكان نيز

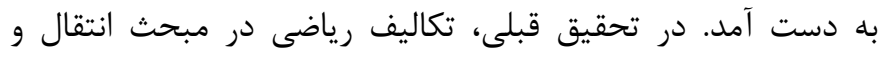

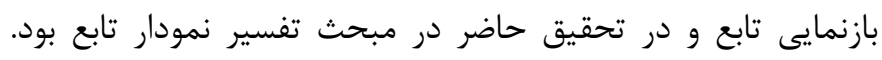

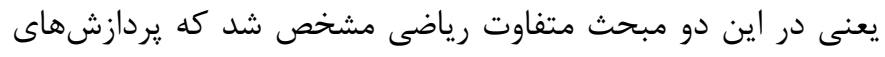

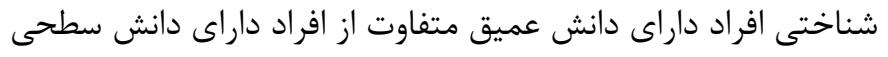

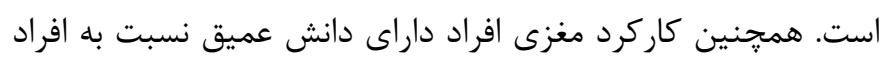

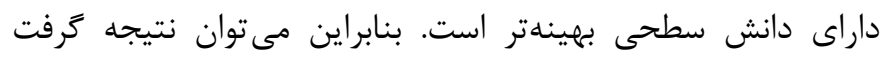
كه درك عميق فراگيران در اين دو مبحث رياضى مانى مى تواند منجر

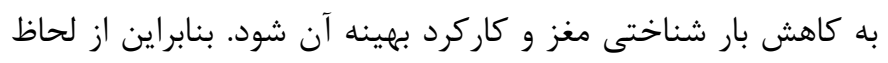

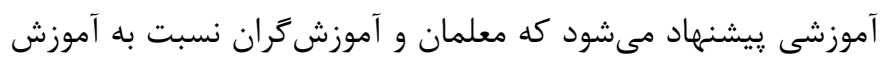
مفهومى و رويهاى عميق اين مباحث رياضى، اهتمام بيشترى داشته

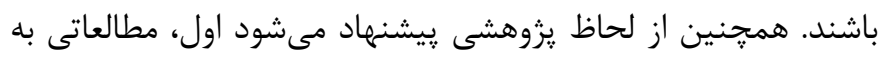

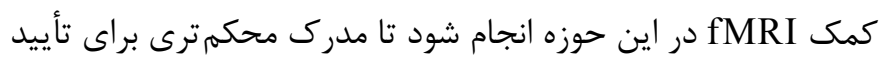

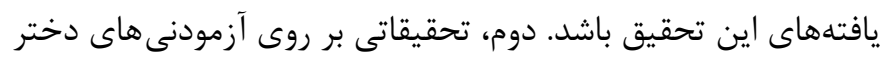

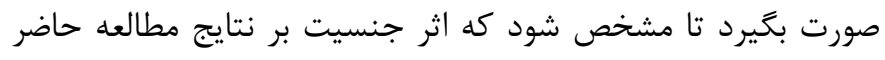

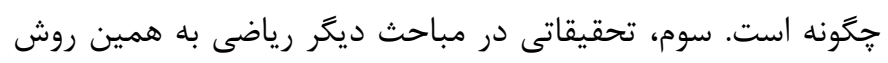

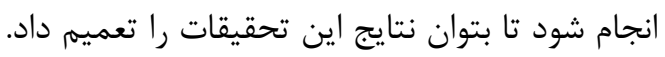

\section{تشكر و قدروانى}

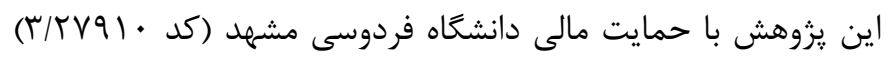

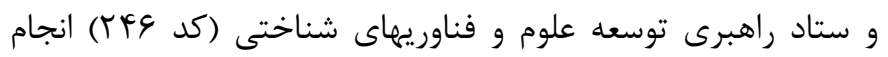

كَفت؛ تكاليف تفسير نمودار تابع، براى گروه دانش سطحى، خواسته هاى

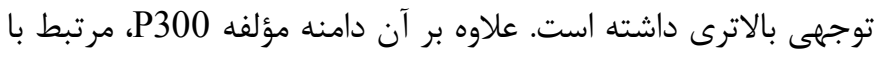

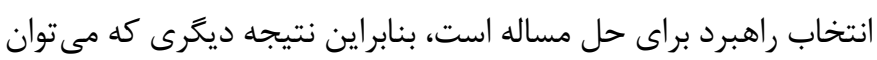

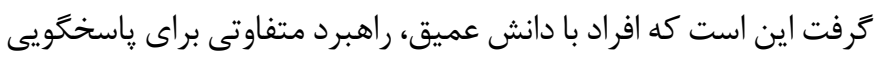

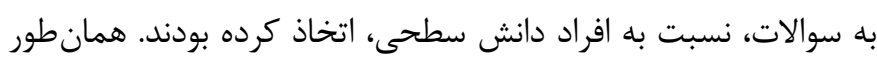

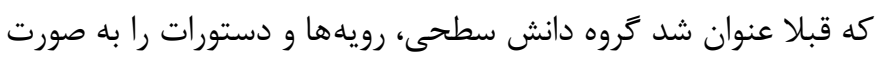

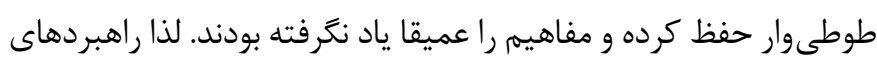

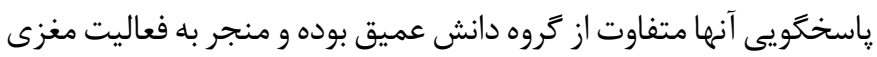
بيشترى در آنها شده بود. از طرف ديكر، اين تحقيق همسو با تحقيقات

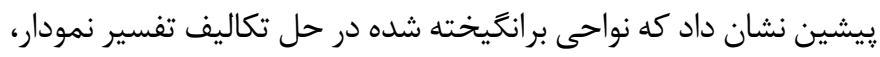

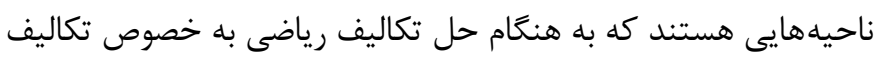

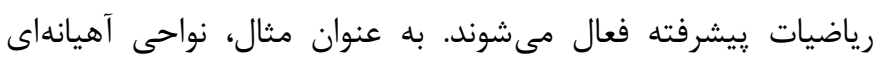

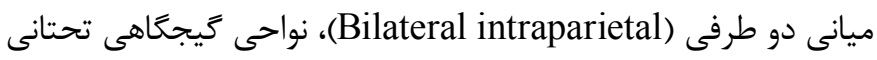
(Inferior temporali)

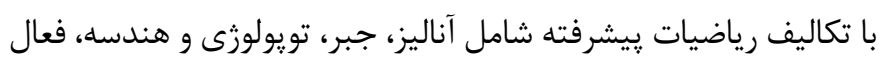

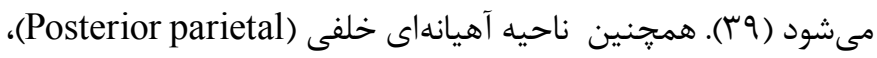

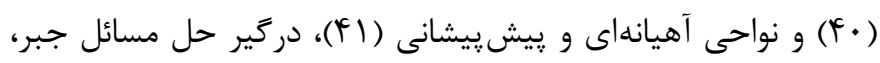

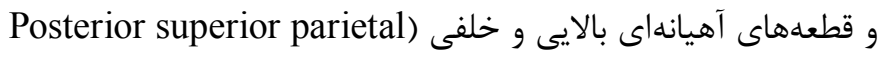

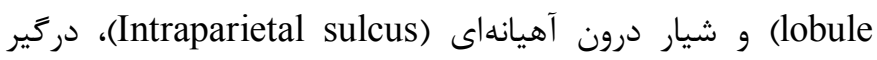

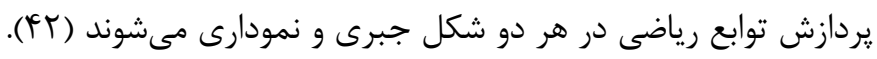

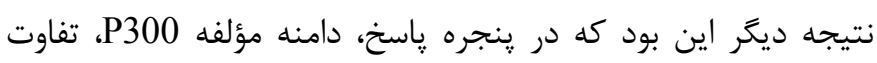
معنادارى در دو گروه دانش عميق و دانش سطحى نداشت. بنابراين

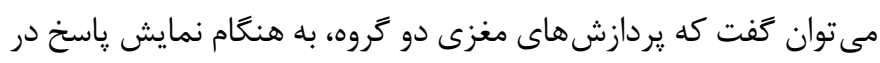

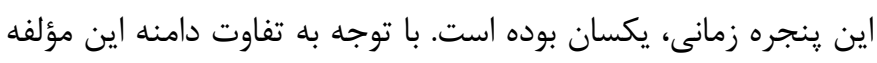

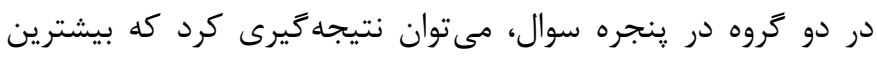

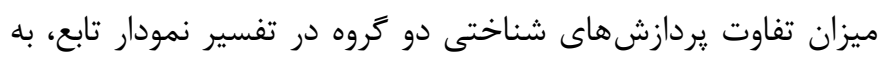

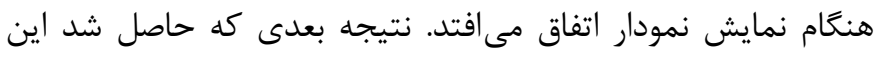

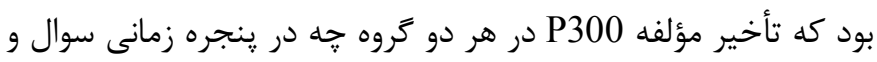
جه در ينجره زمانى ياسخ با يكديكر تفاوت معنادارى نداشت. اين بدان

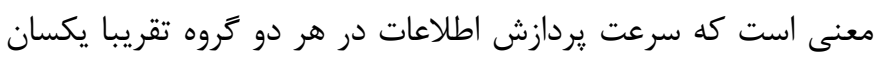

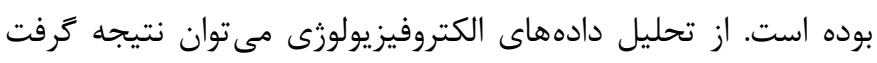
كه يردازش هاى مغزى افراد گروهى كه دانش سطحى در اده تفسير نمودار

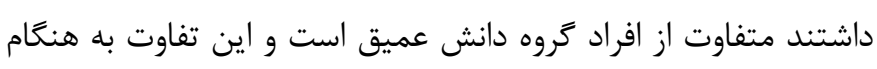
نمايش نمودار آشكار مى شود.

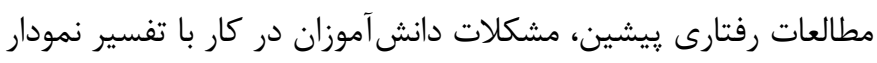

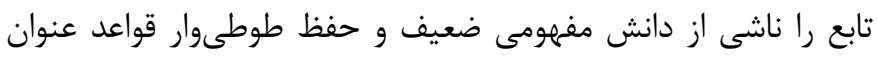

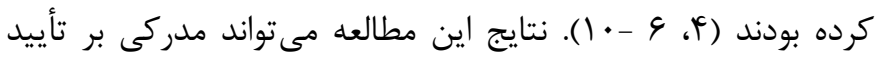




\section{References}

1. Leinhardt G, Zaslavsky O, Stein MK. Functions, graphs, and graphing: Tasks, learning, and teaching. Review of Educational Research. 1990;60(1):1-64.

2. Glazer N. Challenges with graph interpretation: A review of the literature. Studies in Science Education. 2011;47(2):183-210. 3. Bellmer, S. Cognitive structures and students' understanding of mathematics. 15th SEFI MWG Seminar and 8th Workshop GFC. 2010 June 20-23; Wismar, Germany;2010.

4. Baker B, Cooley L, Trigueros M. A calculus graphing schema. Journal for Research in Mathematics Education. 2000;31(5):557-578.

5. Aspinwall L, Shaw KL, Presmeg NC. Uncontrollable mental imagery: Graphical connections between a function and its derivative. Educational Studies in Mathematics. 1997;33(3):301-317.

6. Abbey KD. Students' understanding of deriving properties of a function's graph from the sign chart of the first derivative [PhD Dissertation]. Orono:University of Maine;2008.

7. Asiala M, Cottrill J, Dubinsky E, Schwingendorf KE. The development of students' graphical understanding of the derivative. The Journal of Mathematical Behavior. 1997;16(4):399-431.

8. Orton A. Students' understanding of differentiation. Educational Studies in Mathematics. 1983;14(3):235-250.

9. Selden J, Selden A, Mason A. Even good calculus students can’t solve non routine problems. In Kaput, JJ, Dubinsky E, editors. Research Issues in Undergraduate Mathematics Learning, MAA Notes 33. Washington, DC:Mathematical Association of America;1994. pp. 19-26.

10. Ubuz B. Interpreting a graph and constructing its derivative graph: Stability and change in students' conceptions. International Journal of Mathematical Education in Science and Technology. 2007;38(5):609-637.

11. Hiebert J, Carpenter TP. Learning and teaching with understanding. In: Grouws DA, editor. Handbook of research on mathematics teaching and learning. Virginia:A project of the National Council of Teachers of Mathematics;1992. pp. 65-97. 12. Hiebert J, Lefevre P. Conceptual and procedural knowledge in mathematics: An introductory analysis. In Hiebert J, editor. Conceptual and procedural knowledge: The case of mathematics. New York:Lawrence Erlbaum Associates Inc;1986. pp. 1-27. 13. Rittle-Johnson B, Schneider M. Developing conceptual and procedural knowledge of mathematics. In: Cohen Kadosh R, Dowker A, editors. Oxford handbook of numerical cognition. Oxford:Oxford University Press;2014. pp.1102-1118.

14. Baroody AJ, Feil Y, Johnson AR. An alternative reconceptualization of procedural and conceptual knowledge. Journal for Research in Mathematics Education. 2007;38(2):115-131.

15. Star JR. Reconceptualizing procedural knowledge. Journal for Research in Mathematics Education. 2005;36(5):404-411.

16. De Smedt B, Verschaffel L. Traveling down the road: from cognitive neuroscience to mathematics education... and back. ZDM Mathematics Education. 2010;42(6):649-654.

17. Picton TW, Bentin S, Berg P, Donchin E, Hillyard SA, Johnson R, et al. Guidelines for using human event-related potentials to study cognition: Recording standards and publication criteria. Psychophysiology. 2000;37(2):127-152.

18. Nunez-Pena MI, Gracia-Bafalluy M, Tubau E. Individual differences in arithmetic skill reflected in event-related brain potentials. International Journal of Psychophysiology. 2011;80(2):143-149.

19. Leikin R, Leikin M, Waisman I. What is special about the brain activity of mathematically gifted adolescents? In: Leikin R., Sriraman B, editors. Creativity and Giftedness. New York:Springer Cham;2017. pp. 165-181

20. Waisman I, Leikin M, Shaul S, Leikin R. Brain activity associated with translation between graphical and symbolic representations of functions in generally gifted and excelling in mathematics adolescents. International Journal of Science and Mathematics Education. 2014;12(3):669-696.

21. Linden DE. The P300: Where in the brain is it produced and what does it tell us?. The Neuroscientist. 2005;11(6):563-576. 22. Johnson R. The amplitude of the P300 component of the event-related potential: Review and synthesis. Advances in 
Psychophysiology. 1988;3:69-137.

23. Jost K, Beinhoff U, Hennighausen E, Rösler F. Facts, rules, and strategies in single-digit multiplication: Evidence from event-related brain potentials. Cognitive Brain Research. 2004;20(2):183-193. 24. Kok A. On the utility of P3 amplitude as a measure of processing capacity. Psychophysiology. 2001;38(3):557-577.

25. Wilson GF, Swain CR, Ullsperger P. ERP components elicited in response to warning stimuli: The influence of task difficulty. Biological Psychology. 1998;47(2):137-158.

26. Kok A. Event-related-potential (ERP) reflections of mental resources: A review and synthesis. Biological Psychology. 1997;45(1-3):19-56.

27. Bajric J, Rösler F, Heil M, Hennighausen E. On separating processes of event categorization, task preparation, and mental rotation proper in a handedness recognition task. Psychophysiology. 1999;36(3):399-408.

28. Kiefer M, Marzinzik F, Weisbrod M, Scherg M, Spitzer M. The time course of brain activations during response inhibition: Evidence from event-related potentials in a go/no go task. Neuroreport. 1998;9(4):765-770.

29. Wang L, Xu G, Yang S, Song Y, Wei Y, Yan W. Research on Event Related Potential elicited by number recognizing and arithmetic calculating. In Noninvasive Functional Source Imaging of the Brain and Heart and the International Conference on Functional Biomedical Imaging, 2007. Joint Meeting of the 6th International Symposium on 2007 Oct 12; Hangzhou, China. (pp. 247-250). IEEE.

30. Polich J. Updating P300: An integrative theory of P3a and P3b. Clinical Neurophysiology. 2007;118(10):2128-2148.

31. Yagoubi RE, Lemaire P, Besson M. Effects of aging on arithmetic problem-solving: An event-related brain potential study. Journal of Cognitive Neuroscience. 2005;17(1):37-50.

32. Leikin M, Waisman I, Shaul S, Leikin R. Brain activity associated with translation from a visual to a symbolic representation in algebra and geometry. Journal of Integrative Neuroscience. 2014;13(1):35-59.

33. Nunez-Pena MI, Cortinas M, Escera C. Problem size effect and processing strategies in mental arithmetic. Neuroreport. 2006;17(4):357-360.

34. Houlihan M, Stelmack R, Campbell K. Intelligence and the effects of perceptual processing demands, task difficulty and processing speed on P300, reaction time and movement time. Intelligence. 1998;26(1):9-25.

35. Farsad N, Alamolhodaei H, Moghimi A, Moghimi S, Jabbari Nooghabi M. The comparison of P300 amplitude in students with high and low conceptual and procedural knowledge on graphical and algebraic representation of function. The Journal of Neuropsychology. 2018;3(11):55-70. (Persian)

36. Engelbrecht J, Hardin, A, Potgieter M. Undergraduate students' performance and confidence in procedural and conceptual mathematics. International Journal of Mathematical Education in Science and Technology. 2005;36(7):701-712.

37. Heidari Charvadeh, M. A guide assessment to reliability and validity in the social-cultural research. Mashhad:ACECR-Mashhad Publication;2010. (Persian)

38. Draheim C, Hicks KL, Engle RW. Combining reaction time and accuracy: The relationship between working memory capacity and task switching as a case example. Perspectives on Psychological Science. 2016;11(1):133-155.

39. Amalric M, Dehaene S. Origins of the brain networks for advanced mathematics in expert mathematicians. Proceedings of the National Academy of Sciences. 2016;113(18):4909-4917. 40. Sohn MH, Goode A, Koedinger KR, Stenger VA, Fissell K, Carter CS, et al. Behavioral equivalence, but not neural equivalence - neural evidence of alternative strategies in mathematical thinking. Nature Neuroscience. 2004;7(11):1193-1194.

41. Danker JF, Anderson JR. The roles of prefrontal and posterior parietal cortex in algebra problem solving: A case of using cognitive modeling to inform neuroimaging data. Neuroimage. 2007;35(3):1365-1377.

42. Thomas MO, Wilson AJ, Corballis MC, Lim VK, Yoon C. Evidence from cognitive neuroscience for the role of graphical and algebraic representations in understanding function. ZDM Mathematics Education. 2010;42(6):607-619. 